\title{
THE ROLE OF POLITICAL FACTORS IN THE URBANISATION AND REGIONAL DEVELOPMENT OF ROMANIA
}

\author{
Radu SĂGEATĂ \\ Intitute of Geography of the Romanian Academy, Bucharest, Romania
}

\begin{abstract}
The industrial development policy focusing on heavy industry, mainly the steel and machine-construction branches, was a characteristic feature of the socialist-type political systems of Eastern Europe. Its notable consequence for the system of human settlements translated into forcible urbanisation, but only insofar as quantity was concerned (artificial multiplication of towns and of the town population). As industrial units set up, some villages, functioning as dormitories, would be turned into towns: other would be integrated into the urban administrative territory; on the other hand, some dominantly rural residential districts would be attached to the town and a new type of settlements, connected with the construction of big industrial estates, would be built on empty terrain. As a result, a new type of town-integrated settlements would emerge, but the quality of their urban-type infrastructure falls far below that of traditional centres. Their individual character is marked by a fluctuating evolution, in the majority of cases much closer to countryside, that is, decreasing population and growing vulnerability connected with the units they had been engendered by. Considering the foregoing, we could say that these settlements, now part of the town, represent a distinct, intermediary category between the urban and the rural system and should be designated as such. The state capital determines a specific organisation of the state territory, as materialised in a certain pattern of communication routes and a specific layout of the other urban nuclei with macroterritorial functions. Bucharest's peripheral position within the national territory calls for the decentralisation of its functions concomitantly with remote regional metropoles becoming more important as spatial structuring nuclei. Bucharest's high degree of hypertrophy compared to the second city in the urban hierarchy, together with its distinct position within the Romanian urban system, asked for a distinctive organisation of its built-in area as early as the beginning of the 20 -th century.
\end{abstract}

Key Words: politics, urbanisation, industrial development, demographic fluxes, Romania.

\section{Introduction}

Looking at the structure and organisation of the Central and East-European space, one finds traces of the Soviet-based model of planning, which in 1945 had already been experimented in the USSR for 25 years. That model was deemed appropriate for the states had just fallen under Soviet influence after the Yalta Conference. The model relied essentially on economic growth through hypertrophic industrial development, with highlight on industry, on the heavy industry in particular, the promotion of the working class and on defence-related investment, within an autarchic framework connected with the global economic constraints of the period. This was the substrate of Valev's theory of superstate complexes advanced in the early 1960s. According to that theory, economic integration was to be achieved by having the countries specialise in certain branches and bringing them together into macro-territorial complexes. Such a complex was the Lower Danube, conceived to include the former socialist states, with the Soviet Union playing the leading role. The Romanian and the Bulgarian economies were to specialise in the production of raw materials and semifabs, and become major outlets for the 
high-processed items of East Germany, Czechoslovakia, Poland and Hungary, the "first-liners", forming kind of a buffer zone to Western Europe. Their integration - economical (CMEA-based), political and military (under the Warsaw Treaty), massively backed by the presence of Soviet troops in most of these countries, was to make this superstate complex viable, a nucleus open to other states and tempting them to adhere to it. However, the ever depleting living standard and growing interference of politics in the social life, triggered a chain of revendicative actions both on the social and the political domains. The first took place in June 1956, when Polish workers from Poznan rose under the slogan of "bread and freedom", followed by similar events in Hungary in the Fall of 1956, and the "Spring of Prague" in 1968. Noteworthy is the Romanian political Declaration of April 1964, claiming a country's right to find its road if domestic development. Other notable events were the split in the Soviet-Albanian relations and the consequences of the crisis affecting Soviet-Chinese relations at the beginning of the 6th decade of the 20th Century. Against that unstable background, the Soviet leaders tried desperately to reform the system, illustrated by Krushchev's weak attemptes to destalinisation at the 22nd Congress of the Soviet Communist Party (October 1961), or the Kosygin Reform of 1966. But, failing to attain the desired goal, at the July 1968 Warsaw Pact Meeting Brezhnev would put forward the limited sovereignty concept for the Eastern countries, the real substrate of their aggregation into the "superstate complex" of the Lower Danube and cooperation within the CMEA or Warsaw Treaty schemes.

What shaped a new, original geographical configuration for the Eastern-European states was planned development subordinated to the political factor, state control over the means of production and of exchange; the trend towards an equalitarian development irrespective of their different potential and industrial specificity, restrictive migration to large cities impeding their advancement; the collective-based development of agriculture; a close correlation between the production of these states and the economic and military needs of the USSR; autarchy and split with the West and the ambitious programmes of economic and social development and modernisation. That policy differentiated the Eastern European countries and its effects are felt to this day.

Basic indicators of former socialist countries on the eve of their revolutions

\begin{tabular}{|c|c|c|c|c|c|c|c|c|c|}
\hline \multirow[t]{2}{*}{ State } & \multicolumn{3}{|c|}{ Annual GDP growth } & \multicolumn{6}{|c|}{ Living standard (1987) } \\
\hline & $\begin{array}{l}\text { GDP/ } \\
\text { cap } \\
\text { USD }\end{array}$ & $\begin{array}{c}1981- \\
1985 \\
(\%)\end{array}$ & $\begin{array}{c}1986- \\
1988 \\
(\%)\end{array}$ & $\begin{array}{l}\text { Cars/ } \\
1,000 \\
\text { capita }\end{array}$ & $\begin{array}{c}\text { Tele } \\
\text { phones/ } \\
1,000 \\
\text { capita }\end{array}$ & $\begin{array}{c}\text { Active } \\
\text { farming } \\
\text { population }\end{array}$ & $\begin{array}{l}\text { Private } \\
\text { units } \\
\text { (\% of } \\
\text { GDP) }\end{array}$ & $\begin{array}{c}\text { Exports of } \\
\text { goods (\% } \\
\text { of GDP } \\
\text { '88) }\end{array}$ & $\begin{array}{c}\text { Urbanisa } \\
\text { tion grade } \\
(\%-1991 \\
* 1983)\end{array}$ \\
\hline USSR & 5552 & 1.7 & 2.3 & 50 & 124 & 21.7 & 2.5 & 6.8 & $64.8^{*}$ \\
\hline Bulgaria & 5633 & 0.8 & $\overline{1.9}$ & 127 & 248 & 19.5 & 8.9 & 23.0 & 70 \\
\hline $\begin{array}{l}\text { Czecho- } \\
\text { slovakia }\end{array}$ & 7603 & 1.2 & 1.5 & 182 & 246 & 12.1 & 3.1 & 19.7 & $66.7^{*}$ \\
\hline DDR & 9361 & 1.9 & 1.7 & 206 & 233 & 10.2 & 3.5 & 13.7 & $77^{*}$ \\
\hline Hungary & 6491 & 0.7 & 1.5 & 153 & 152 & 18.4 & 14.6 & 14.7 & 61 \\
\hline Poland & 5453 & 0.6 & 1.0 & 74 & 122 & 28.2 & 14.7 & 6.4 & 62 \\
\hline Romania & 4117 & -0.1 & 0.1 & 11 & 111 & 28.5 & 2.5 & 11.2 & 54 \\
\hline
\end{tabular}

Source: Fetjö François, 1997, La fin des democraties populaires. Les chemins du post-communisme, Ed. Du Seuil, Paris.

The Soviet space model has certainly produced poorly developed and dependent economic territorial structures, but it also created a framework for the real modernisation of these states 
that had neither industrial tradition, nor an evolved urban infrastructure. The main economic and social indicators of the former socialist countries on the eve of the revolutionary year 1989 list Romania at the bottom of the table, with GDP stagnant values (Fourcher, 1993) (Table 1).

\section{Socialist towns in Romania (1945-1989)}

As previously discussed, the urban category seriously marked by rural features as far as quality is concerned, are the settlements turned into towns during the 20th century, mainly after 1945, when the forcible industrialisation drove entailed big migratory fluxes from the countryside. This politically monoeuvred oversized urbanisation was not correlated with the urban centres' absorption capacity.

Fast-going development, associated with permanent austerity programmes, triggered serious dysfunctionalities of the built-in structures materialised in the discordance between built area and infrastructure. The question is, whether changing the status of rural settlements for a town rank does really have a major impact on their evolution, whether turning a commune into town means faster development than if left at the rural level. In order to find it out we analysed a sample representative for the evolution of the Romanian urban system namely, settlements turned into towns after 1945

As a result, four urban categories were depicted as follows (Fig. 1):

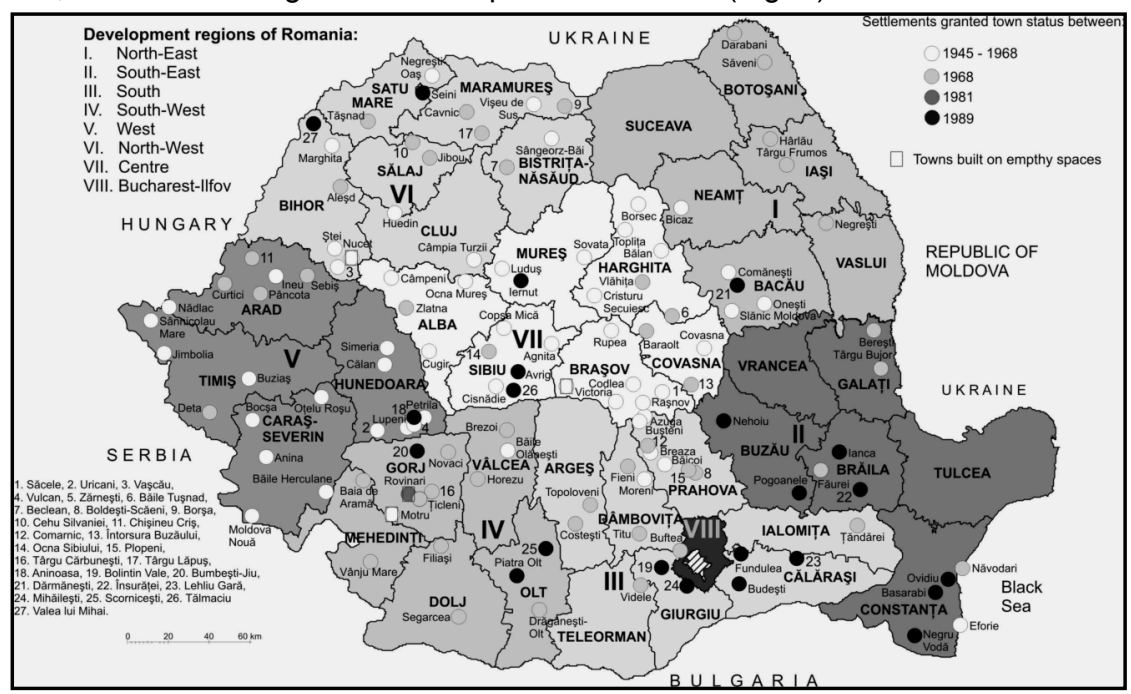

Fig.1 - Settlements granted towns status between 1945 and 1989.

1. Settlements raised to town status between 1945-1968, in line with the Soviet-type brand of socialism, and administrative-territorial division by regions and districts of Soviet inspiration.

This category groups the largest number of towns: 56 , of which only 12 have advanced in the urban hierarchy. Noteworthy are Oneşti and Zărneşti (which gained 49 and 47 seats, respectively), after petrochemical and machine-building units were set up there. At the other end of the spectrum, are some towns from the western Romania which registered dramatic decreases of population through depleted birth rates (Banat and Crisana regions) and 
emigration of part of the active population either to large cities (Timişoara, Arad, Oradea, Satu Mare and Baia Mare) or abroad. A representative case make the towns of Nucet and Vaşcău. The former, developed due to mining, is one of the few towns in Romania without railroad access. Its population dropped 3.5 times, the town losing 156 seats in the national urban hierarchy. Vaşcău registered a 32.5\% decrease of population and lost 104 hierarchical seats. Both localities fall into the small town category, with a dominant mining profile.

Other small towns, agro-industrial generally, though not undergoing major demographic shifts, have nevertheless lost important positions in the urban system (22-51 seats): Nădlac and Jimbolia (customs points), Ineu, Câmpeni, Sânnicolau Mare, Ştei, Huedin and Vişeu de Sus.

A category recording striking rank regression are the mining towns, whether in Petroşani Depression and Gorj Couty (Petrila, Lupeni, Motru and Rovinari) or in the Banat Mts. (Anina, Moldova Nouă). Moreover, the decline of mining was not associated with effective reconversion of the labour force to other activities.

Touristic cities, in their turn, experienced a demographic upsurge, but soon enough registered major losses in the urban hierarchy (Azuga, Băile Herculane, Băile Olăneşti, Borsec, Breaza, Buşteni, Buziaş, Covasna, Eforie, Slănic Moldova and Sovata). In the same situation are certain industrial towns situated in the proximity of some regional metropoles (Rupea and Săcele near Braşov, Cisnădie close to Sibiu etc.); others have a high-polluting industry on their territory, structural readjustment entailing massive lay-offs (Copşa Mică and Bicaz).

2. Settlements nominated towns in 1968, in the wake of a policy of estrangement from the USSR; a new administrative-territorial organisation with the county as basic unit.

That moment marked the beginning of a transition period for the Romanian urban system and, as some towns were evolving at different rates, changes in the relationships among the urban centres would emerge. Out of the 48 towns listed in this category, only 13 had a positive hierarchical evolution eg. Năvodari, registered an explosive upsurge of 129 seats after turning industrial and discharging port activities, Târgu Frumos (given the rank of town for the second time, after losing it in 1950) mounted 69 seats in the urban hierarchy. The diversification of its industrial profile turned it into a local convergence centre in the area spanning the distance between the towns of Paşcani and laşi. On the other hand, this same category could experience rank regression, associated occasionally with demographic losses (Cavnic, Chişineu-Criş, Curtici, Ocna Sibiului, Vânju Mare and Zlatna).

3. Settlements raised to town rank over the 1968-1989 period showed relative stability of their administrative-territorial structures.

Throughout that interval, one town alone, Rovinari, a mining centre in Oltenia coal basin, registered a positive dynamic, gaining 58 seats in the urban hierarchy and a $58.5 \%$ increase of inhabitants.

4. Settlements declared towns in 1989, when the communist system was deteriorating and the evolution of the urban system was marked by relative turbulence.

This category lists 23 local polarisation centres, most of them discharging agro-industrial functions. The decision to turn them into towns was taken in order to strike a balance between regional socio-economic phenomena, on the one hand and to consolidate some county urban systems, on the other (Buzău, Călăraşi, Brăila and Giurgiu) (lanoş, Tălângă, 1994). The urban 
evolution was affected by the economic and social situation of transition from the centralised economy to the market system. In most cases, the result was fluctuating evolutions, with stagnations and mild decreases of population. An exception was the town of Mioveni, the largest and most dynamic one in this category. As investments were put into "Dacia" car factory it took 30 more seats due to a $66.2 \%$ population growth.

Positive evolutions registered also mining towns: Bumbeşti-Jiu and Aninoasa; the dominantly industrial Avrig, Ovidiu and Nehoiu, and the agro-industrial lanca and Scorniceşti. However, forecasting their long-term evoluation is hazardous because of the short time elapsed since they have been assigned that rank, and the economic-social convulsions shaking the Romanian society due, among others, to an incoherent legislation.

The policy of promoting heavy industry development, of the steel and building-material sectors in particular, was characteristic of the Eastern-European socialist political systems. It also had a major impact on the settlement system (artificial, forcible urbanisation got only as far as quantity was concerned; artificial numerical increase of towns and of the urban population ratio). Attaining that policy goal involved four lines of approach: the transformation of some villages into towns by the implantation of industrial units; integration of some villages ("dormitory settlements") into the urban administrative territory; englobing some dominantly rural districts into the built-in area, and last but not least, the construction on empty terrain of some towns connected with big manufactures. The outcome has been a type of settlements, integrated into the urban environment, which in terms of quality, of the urban-type infrastructure fall short of traditional urban centres.

What characterises them is a fluctuating evolution, closer to rural settlements, with population decreases and a high degree of vulnerability given that the industries that had generated them are regressing. Therefore, these settlements, presently part of the urban system, represent actually a distinct category, standing in-between the urban and the rural systems, and should be depicted as such.

\section{New towns in Romania (1990-2009)}

The latest category, settlements promoted to the position of town in the post-communist era (1990-2007) including 54 polarisation centres. Is rather heterogeneous functionally: Otopeni, Teiuş and Bechet are specialised in transports (airport, railway knot and fluvial harbour respectively); Baia de Arieş, Băbeni and Berbeşti in mining; Fiebinți-Târg, Miercurea Nirajului and Potcoava in oil and gas exploitations; Amara, Geoagiu and Tismana in tourism; Turceni, Sângeorgiu de Pădure and Roznov in industry (thermal power stations and chemical industry); Ardud, Bălceşti, Ciacova, Dăbuleni, Gătaia, Pecica, Murgeni, Sântana in agriculture (Fig. 2).

They also have distinct locations, some are found in deeply rural areas (Făget, Baia de Arieş, Dăbuleni, Geoagiu, Bălceşti, Pătârlagele, Tismana, Murgeni), others in the proximity of polarising urban centres (Otopeni, Popeşti-Leordeni, Voluntari, Chitila, Pantelimon, Măgurele, Bragadiru). The majority originate from communes with many villages under their administration, a very dispersed population and a low technical-constructional endowment.

This trend of evolution in the rural-urban interface is the increasing transformation of communes, viewed as local polarisation cores, into towns (Law No. 351/2001, annex II-6.1. designated 17 zones with no town within a radius of $25-30 \mathrm{~km}$ which were to develop urgently into localities with inter-communal servicing role). In this way, the Romanian urban system was enlarged (2001-2005) with 53 of the 58 settlements raised to town status after 1989. 


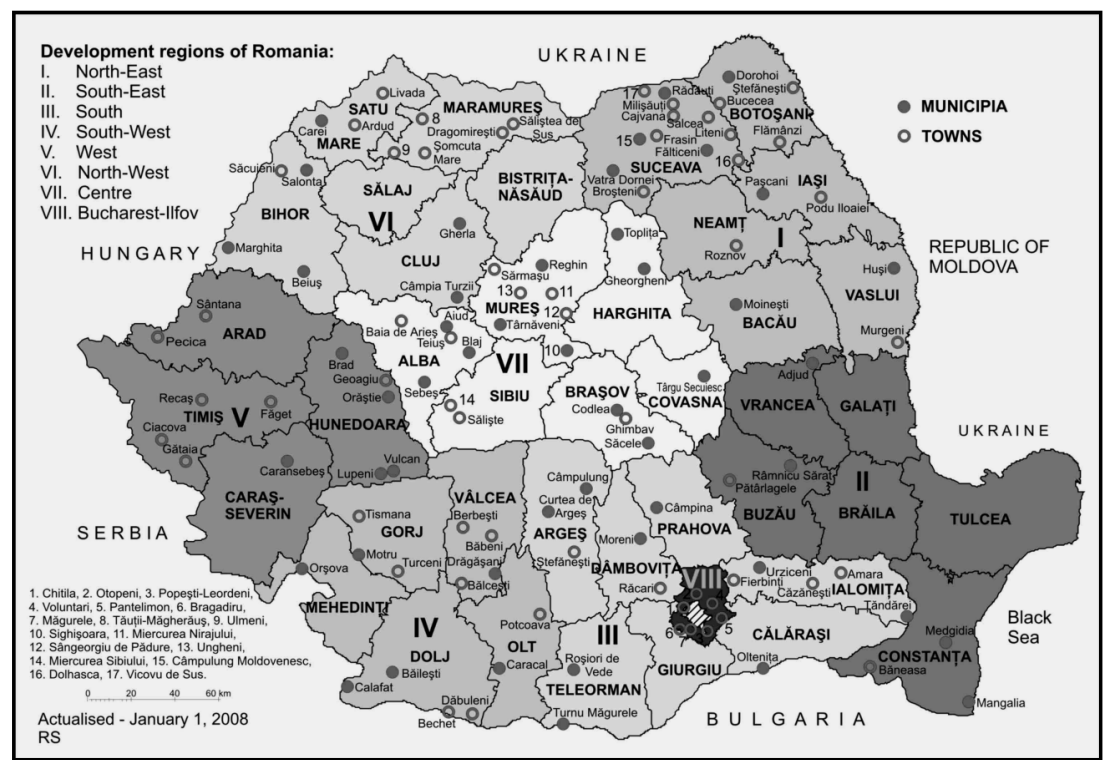

Fig. 2 - Settlements granted towns status between 1990 and 2009

Their demographic size, physiognomy and moreover functional profile justify our assumtion that post-revolutionary urbanisation, just like the urbanisation pursued in the years of centralised economy, had an extensive, quantitative character rather than intensive, qualitative attributes capable to create better urban confort and functional convergence between the top and the bottom of the urban hierarchy (Săgeată, 2004, 2006).

Multiplying the number of towns, in the conditions in which large areas are not, or are little polarised by an urban core, is a positive intention, but it tends to remain simply declarative if these towns are not capable to grow into real local polarisation nuclei and play a coagulating role in the territory.

Besides, the minimum legal criteria attached to town status are usually scarcely met, many settlements preserving strong rural traits.

In the absence of standards of quality matching the urban environment, urbanisation imposed by legislation has more often than not a negative impact on the local communities making them lose the EU funds earmarked through rural development programmes. In our view, establishing a category of settlements intermediate between the urban and the rural, similar to the urban communes of the interwar period, would be a solution. These settlements are to be assimilated to the rural, but act as nurseries for the new urban settlements which should rise to town status only after having met the necessary legal criteria.

And last but not least, the third evolution trend which affected the Romanian settlement system after 1990, was municipium status assigned to a great many towns. While the first years of the third millennium saw some communes raising to town status, the last decade of the 20th century, basically the first phase of transition, witnessed some towns being declared municipia. So, all of the 47 new municipia emerged in the post-revolutionary period (1990-2006) received 
this rank over the 1993-2003 period, 37 of them before January 1, 2001.

The question is, what were the criteria behind pushing small towns (with less than 20,000 inhabitants (e.g. Urziceni, Brad, Salonta, Toplița, Orşova, Vatra Dornei, etc.) to the top of the hierarchy, and moreover, if those legislative initiatives really boosted the socio-economical development of the respective local communities.

Where as most municipia boast a complex industrial profile, some are one-industry towns (Câmpia Turzii and Hunedoara), agro-industrial towns (Urziceni, Salonta, Roşiori de Vede and Caracal), towns specialised in the forestry economy (Brad), or tourism (Vatra Dornei and Mangalia). Just like in the 1965-1980 interval, the diversification index of industrial branches registered highest values in those municipia which had experienced soaring developments in the years of centralised economy. Hence their vulnerability, caused on the one hand, by artificial production relations between industrial partners and on the other hand, by the disparity between the town's industrial profile and the resources of the urban influence zone. As a result, inter-municipia relationships also suffered some changes.

There are cases when location was the factor that determined granting a municipium status to some towns. Thus, in intensely rural areas, with small-town networks (e.g. in the Apuseni Mts, in the Getic Piedmont, or in south-western Oltenia), some polarising centres should be singled out to coordinating the socio-economical activities. Turning such towns into municipia (Brad, Drăgăşani, Calafat, Salonta or Toplița) might attract investments liable to contributing to their becoming growth poles for the respective zones.

Assigning a municipium rank to towns situated on the median or lower scale of the urban hierachy widened existing gaps in the municipium network of Romania, so that the network is showing an obvious disproportion in terms of demographic size, economic and location potential. The municipial population varies between 1,926,334 inhabitants (Bucharest) and 10,996 inhabitants (Beiuş, March 18, 2002) and if Bucharest is left out of the equation, then the relation between extreme sizes slides from 175/1 to 23/1. The fact that the demographic size of some municipia occupying the higher ranks of the hierarchy is bigger than some counties (e.g. Covasna, Ilfov, sălaj, Tulcea, Giurgiu or lalomița) calls for deep-going reconsideration of their administrative pattern by the creation of districts inside their boundaries similar to those existing in Bucharest. Densities within the built-up area of these municipia also vary widely, from over $10,000 \mathrm{inh} . / \mathrm{km}^{2}$ (even $21,855 \mathrm{inh} . / \mathrm{km}^{2}$ in Oneşti to a record high of $42,602 \mathrm{inh} . / \mathrm{km}^{2}$ in Orăştie) to under $1,000 \mathrm{inh} . / \mathrm{km}^{2}$.

In view of the above, we assume that municipium status after 1990 was often considered the optimum, even miraculous solution, for the socio-economical revival of some declining towns, and a chance to attract investments therein. This way, a disparity cropped up between their real development potential and the political-administrative decisions which tended to blur the dysfunctions produced by the excessive industrialisation drive of the old centralised economy. Rapidly, the lack of prospects of such a development model became apparent, their socioeconomical progress being little stimulated by legislative initiatives. Therefore, reshuffling the network of municipia is an imperative necessity, supposedly affecting the towns with under 50,000 inhabitants, which might be demoted from this rank.

\section{References}

ENYEDI G. (1992), Urbanisation in East Central Europe: Social and Societal Responses in the State Socialist Systems, Urban Studies, vol. 29, no. 6, p. 869-880. 
FOURCHER M. (edt.) (1993), European Fragments, Fayard, Paris, 317 p. (in French). GHINEA D. (1996), The Geographical Encyclopedia of Romania, I, Ed. Enciclopedica, Bucharest, 225-321 (in Romanian).

IANOŞ I. (1987), Towns and the Organisation of the Geographical space. Studies of Econonic geography on Romania's territory, Ed. Academiei, Bucharest, 152 p. (in Romanian with English summary).

IANOŞ I., TĂLÂNGĂ C. (1994), Township and Urban system in Romania in the early Period of transition to the Market economy, Romanian Academy, Institute of Geography, Bucharest, 127 p. (in Romanian with English summary).

IANOŞ I. (2005), Urban Dynamics. Applications on the City and the Romanian Urban System, Ed. Tehnică, Bucharest, 213 p. (in Romanian with English summary).

IANOŞ I., HELLER W. (2006), Space, Economy and Settlement Systems, Ed. Tehnică, Bucharest, 373 p. (in Romanian with English summary).

ILIEŞ AI., WENDT J. (edt.) (2001), Political Geography Studies in Central and Eastern Europe, University of Oradea, $117 \mathrm{p}$.

Le BRETON J.-M. (1996), Central and Eastern Europe between 1917 and 1990, Cavaliotti, Bucharest, 306 p.(in Romanian).

MIHĂILESCU V. (2003), Bucharest's Geographical Evolution, Paideia, Bucharest, 234 p. (in Romanian).

POSEA Gr., ŞTEFĂNESCU I. (1984), Bucharest and Ilfov Agricultural Sector, Romanian Academy, Bucharest, 290 p. (in Romanian).

SĂGEATĂ R. (1999), The Municipia - between Political decisions making and the Economic realities, Comunicări de Geografie, vol. IV, University of Bucharest, p. 433-438.

SĂGEATĂ R. (2001-2002), The Administrative-territorial organisation of the City of Bucharest. Evolution and Optimisation proposals, Revue Roumaine de Géographie, t. 45-46, p.153-165.

SĂGEATĂ R. (2004), Models of Political-Administrative Regionalisation of the Territory, Top Form, Bucharest, 117 p. (in Romanian with English summary).

SĂGEATĂ R. (2006), Political-administrative function of the Human settlements and the

Organisation of the Geographical space. Geographical study with application of Romanian territrory, Ed. Universității Naționale de Apărare „Carol I", Top Form, Bucharest, 393 p. (in Romanian with English summary).

SĂGEATĂ R., SIMILEANU V. (2007), Political-Administrative Decisions, a Pressure Factor for Entrepreneurial Initiatives, Geographica Timisiensis, vol. XVI, no. 1-2, Timişoara, p. 95-104.

SĂGEATĂ R. (2008), Bucharest. Geographical and Geopolitical Considerations, Revista Română de Geografie Politică, vol. X, no. 1, Oradea, p. 37-56.

SOULET J. F. (1998), A Comparative History of Communist States (1945-1989), Polirom, Historia, laşi, 364 p. (in Romanian).

TURNOCK D. (2001),. A Concise Geography of Eastern Europe: Communism and the Transition, University of Leicester, Department of Geography, 302 p.

WENDT J., ILIEŞ, Al. (edt.) (2001), Chosen problems of Political Geography in Central Europe, Wydawnictwo Uniwersytetu Gdanskiego, 134 p.

Received at : 25.03 .2010

Revised at: 15.04 .2010

Accepted for publication at: 21.05 .2010 